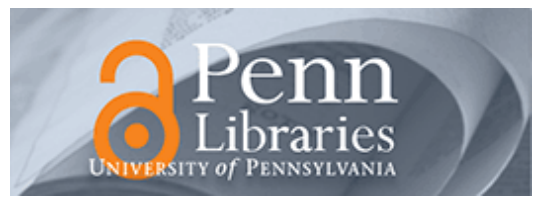

University of Pennsylvania

ScholarlyCommons

Real Estate Papers

Wharton Faculty Research

$1-2009$

\title{
Family Types and the Persistence of Regional Disparities in Europe
}

Gilles Duranton

University of Pennsylvania

Andrés Rodríguez-Pose

Richard Sandall

Follow this and additional works at: https://repository.upenn.edu/real-estate_papers

Part of the Economics Commons, and the Real Estate Commons

\section{Recommended Citation}

Duranton, G., Rodríguez-Pose, A., \& Sandall, R. (2009). Family Types and the Persistence of Regional Disparities in Europe. Economic Geography, 85 (1), 23-47. http://dx.doi.org/10.1111/

j.1944-8287.2008.01002.x

At the time of publication, author Gilles Duranton was affiliated with the University of Toronto. Currently, he is a faculty member at the Real Estate Department at the University of Pennsylvania.

This paper is posted at ScholarlyCommons. https://repository.upenn.edu/real-estate_papers/40

For more information, please contact repository@pobox.upenn.edu. 


\title{
Family Types and the Persistence of Regional Disparities in Europe
}

\begin{abstract}
This article examines the association between one of the most basic institutional forms, the family, and a series of demographic, educational, social, and economic indicators across regions in Europe. Using Emmanuel Todd's classification of medieval European family systems, we identify potential links between family types and regional disparities in household size, educational attainment, social capital, labor participation, sectoral structure, wealth, and inequality. The results indicate that medieval family structures seem to have influenced European regional disparities in virtually every indicator that we considered. That these links remain, despite the influence of the modern state and population migration, suggests that such structures are either extremely resilient or in the past were internalized within other social and economic institutions as they developed.
\end{abstract}

\section{Keywords}

institutions, family types, education, social capital, labor force participation, economic wealth and dynamism, regions, Europe

Disciplines

Economics | Real Estate

\section{Comments}

At the time of publication, author Gilles Duranton was affiliated with the University of Toronto. Currently, he is a faculty member at the Real Estate Department at the University of Pennsylvania. 


\section{Family Types and the Persistence of Regional Disparities in Europe}

\section{Gilles Duranton*, Andrés Rodríguez-Pose** and Richard Sandall***}

November 2008

* SERC, Department of Economics, University of Toronto, Canada

** SERC, Department of Geography \& Environment, London School of Economics

*** Department of Geography \& Environment, London School of Economics

Acknowledgements

We are grateful to Alejandra Castrodad-Rodríguez for outstanding assistance with GIS and to Thomas Farole, Gernot Grabher, four anonymous referees, as well as to participants in seminars at the Universities of Cambridge, Oxford, Warwick, and Paris for their valuable comments to earlier versions of the paper. Duranton gratefully acknowledges financial support from the Canadian Social Sciences and Humanities Research Council and RodríguezPose that of Prociudad-CM. The work was also part of the research programme of the independent UK Spatial Economics Research Centre funded by the Economic and Social Research Council (ESRC), Department for Business, Enterprise and Regulatory Reform, Communities and Local Government, and the Welsh Assembly Government. The views expressed are those of the authors and do not represent the views of the funders. 


\begin{abstract}
$\underline{\text { Abstract }}$
This paper examines the association between one of the most basic institutional forms, the family, and a series of demographic, educational, social, and economic indicators across regions in Europe. Using Emmanuel Todd's classification of medieval European family systems, we identify potential links between family types and regional disparities in household size, educational attainment, social capital, labor participation, sectoral structure, wealth, and inequality. The results indicate that medieval family structures seem to have influenced European regional disparities in virtually every indicator considered. That these links remain, despite the influence of the modern state and population migration, suggests that either such structures are extremely resilient or else they have in the past been internalized within other social and economic institutions as they developed.
\end{abstract}

Keywords: Institutions, family types, education, social capital, labor force participation, economic wealth and dynamism, regions, Europe

JEL Classifications: J12, O18, R11 


\section{Introduction}

The role of institutions as factors shaping human activity has attracted enormous attention in recent years. It has become increasingly clear that institutions, such as political systems (Acemoglu, Johnson and Robinson 2001 and 2005), the legal rights of the individual (North 1990), or the various forms of 'social capital' amongst groups (Putnam, 1993 and 2000; Storper, 1997 and 2005) can have a significant bearing on a society's ability to generate innovation, wealth, and growth. Yet, despite this growing interest, there is little consensus about either the type of institutions that have the greatest impact, or how institutions and their effects evolve over time. This paper examines the role within Europe of an often overlooked institution, the family, and concludes that its importance in determining socio-economic outcomes may have been greatly underestimated. Furthermore, the use of an historical data set allows us to present hypotheses regarding the persistence and evolution of institutions and their influence on contemporary European social and economic disparities.

The importance of institutions is usually deemed to lie in their role in reducing the risks and transaction costs of investment and exchange (Parto, 2005). Dealing with another member of a community to which one belongs and so with someone either known personally, or through a mutual acquaintance, reduces the risk of fraud, unreliability or incompetence (Putnam, 1993, 2000); such examples can be deemed 'informal' or 'community-type' institutions and include norms, traditions and social conventions, interpersonal contacts, relationships, and informal networks (RodríguezPose and Storper, 2006: 1). Dealing with a person bound by law to honor a contract, or a person checked via a credit bureau, for example, illustrates that similar benefits 
can be gained at a societal level through official institutions (North, 1990, Acemoglu et al 2001, 2005). These institutions can be defined as 'formal' or 'society-type' institutions and are usually defined by more transparent and codified rules (Rodríguez-Pose and Storper, 2006: 2). Both formal and informal institutions are deemed to have an influence on socio-economic outcomes (Putnam, 1993) and both have been strongly associated with indicators of innovation and dynamism (Schumpeter, 1926; Putnam, 1993; Storper, 1997 and 2005). In fact, some studies have suggested that the role of institutions in general may be absolutely fundamental to explaining both economic growth and economic disparities. The substantial body of work in recent years of Acemoglu and his collaborators (Acemoglu, Johnson and Robinson 2001 and 2005), for example, argues powerfully that the richest and poorest nations of the world owe their position more than anything to the political and legal institutions they developed or inherited from their colonial masters.

Institutions, however, can also act as a hindrance to economic development. In terms of formal institutions, an overdeveloped system of laws and regulations can increase transaction costs to the point where exchange or investment becomes unattractive. In terms of informal institutions, the very formation of a group implies the exclusion of non-group members, and a lack of transparency and predictability which may engender inefficiencies and corruption. Most work in the field of social capital has tended to focus on the strengths of formal or 'society' institutions in contrast to the weaknesses of informal, 'community' institutions (North, 1990; LaPorta et al, 1999; Rodrik et al, 2004) or vice versa (Granovetter, 1985; Coleman, 1988; Putnam, 2000), while others have involved themselves in debates concerning which of the two is more significant (Durlauf and Fafchamps, 2004). Typically since Weber (1921) 
society-type institutions have been seen as more modern and efficient, and conducive to an industrialized economy, while community-type institutions are seen as backward. More recently, others have attempted to synthesize 'society' and 'community' by noting how each type operates most beneficially in the presence of the other (Storper, 2005; Rodríguez-Pose and Storper, 2006). The latter approach posits that a balance of community and society is required in order to generate bestcase outcomes in terms of micro-economic confidence, social policy and problem solving, all of which are then linked to economic dynamism and growth.

However, there is little in the literature which considers the role of one of humanity's most basic forms of institution, the family, in determining either economic disparities or other forms of social or economic outcomes which have, in turn, an influence over economic development. Although this may underestimate the role of the family as a unit for both production and reproduction, researchers have traditionally assumed that the impact of family structures tends to be lower than that of other institutions, such as the state, religion, or the law, if only because of their small size, the limited range and influence of the transactions that take place within them, and their heterogeneity (see Todd, 1990a, for a discussion on this point). However, some academics have noted strong patterns of family structure, with clear regional variations and persistence over time and linked them to significant social and economic outcomes. This includes the seminal work of Emmanuel Todd (Todd, 1990a; 1990b), upon which this study draws considerably, and the more recent work of Greif $(2005,2006)$.

This paper uses Todd's (1990a) classification of family types in order to determine whether the existence or persistence (either directly or through intermediate 
determinants) of medieval family types are associated with existing regional differences, including household size, educational attainment, labor participation, social capital, sectoral structure, and economic wealth and inequality, across regions of Europe. In so doing we hypothesize that the fundamental drivers behind the persistence of regional disparities across Europe maybe rooted in institutional factors, such as family types and structures, whose origins can be traced at least to the Middle Ages, if not earlier. The paper uses regression analysis to establish the strength of the correlations between family structures and the dependent variables. This analysis enables us to offer some initial ideas regarding the role of family structure both in the development of other institutions and in economic development in general about which, to date, we have known 'surprisingly little' (Greif, 2005, p.2).

The paper is divided into the following sections: first we examine Todd's classification of family structure, including the presentation of a map showing how different family types are spread throughout Europe. Section 2 explains some of the issues surrounding the concept of the persistence of family types throughout history and reviews some of the theories linking family structures to regional economic and institutional outcomes. Section 3 describes the model, while section 4 presents our results, and then analyses them with a view to understanding how they may fit into existing conceptual frameworks. Finally, we conclude by observing that there do indeed appear to be strong links between family types and our dependent variables, and offer some initial thoughts of how this might affect our understanding of institutional and economic development in modern European history. 


\section{Todd's classification of family structures}

Todd's 1990 work (Todd, 1990a, L'invention de l'Europe - The invention of Europe, Paris: Seuil) provides the characterization of family types which forms our key explanatory variable. His classification of families has two main organizing principles. First, families differ in how parents and children interact. At one extreme, children leave the parental nest as soon as they reach (early) adulthood and become independent from parental authority at an early age. At the other extreme, children remain subjected to their parents' authority long after reaching adulthood and even after marrying. In other words, the relationship between parents and children can be thought of as either 'liberal' or 'authoritarian'. The second organizing principle refers to the nature of the relationship between siblings. At one end, siblings (or, at least, brothers) may be treated as equal, whereas, at the other, parents may favor one particular child (often the eldest) at the expense of the others. On this basis, families can be characterized as 'equal' or 'unequal'.

These two oppositions, liberal/authoritarian and equal/unequal, are interesting for several reasons. First, they capture two fundamental dimensions, liberty and equality, which matter both within families and the wider society. With early childhood experiences having some bearing on adult values and behavior (see Gross and McIlveen, 1998, chapters 39, 43, and 44, for an introduction to the vast psychology literature on these issues and also Bisin and Verdier, 2000, for an economic discussion of cultural transmission in the US), these categories provide us with an obvious channel of transmission from 'family values' towards broader economic outcomes. Second, this two-dimensional characterization avoids more simplistic 
oppositions (such as strong versus weak families) which, as we will see in our results, are hard to substantiate empirically. On the other hand, this typology avoids too much complexity and subtlety which would be hard to put to the data. Third, these categories are easy to measure empirically (see below) and most regions of Europe typically fall into one category or the other for both dimensions. Furthermore, it also appears that different family types seldom coexist in the same area.

To measure liberal versus authoritarian families, Todd (1990a) looked at the cohabitation between generations within families, most particularly between parents and their married children. Where familial authority is strong, the eldest son does not leave the family home when he marries, but remains under the authority of the father. Similarly, unmarried adult daughters also typically remain in the family home under the authority of, first, their father and then their brother. These types of family are termed 'stem' families, in contrast to 'nuclear' families where familial authority is said to be weak. Nuclear families only remain together while the children are growing up and, on marrying, or even on reaching adulthood, children leave the parental home. In effect, such children also leave behind their dependence on their parents, and the authority which their parents hold over them.

To obtain systematic data for western Europe, Todd first used censuses from western European countries in the 1950s and 1960s. Using the administrative divisions of the time, he identifies regions of stem families as regions with a 'high' proportion of adult children living with their parents, conditional on the fraction of population working in agriculture (since, all else being equal, parents and married children tend to live together more often in rural areas). By the 1950s and 1960s, the proportion of adult 
children living with their parents in stem family areas was typically low, often less than $10 \%$. In order to check that these areas were historically dominated by stem families, rather than merely 'backward' or otherwise anomalous, Todd went through a very large number of historical monographs about particular regions (nearly 200 are cited in his 1990 book) and verified whether they contradicted his classification. He claims to have found no indication contrary to his original classification and to have made only very small adjustments. Since some of these monographs go back more than 500 years, this is strongly suggestive of lasting and stable patterns (and for this reason we refer to family types as medieval). There is some evidence that these patterns could be even older than this. For instance, the prevalence of stem families in French Brittany, north western Spain, Wales, and Scotland coincides with areas where Celtic populations took refuge two millennia ago. The area of egalitarian families with strong parental authority in central Italy ties in closely with the area of Etruscan civilization in pre-Roman times.

In order to measure equality, Todd followed the same approach of using relatively recent data for the whole of western Europe while checking whether the patterns that were uncovered were reflected in historical monographs. The key indicator of equality and inequality is what happens to family property after the death of the parents. Equality is said to be strongest where family property is divided most evenly between siblings, or (more usually) between brothers. Areas in which equal familial systems are operating are identified, therefore, by inheritance laws and practices. Some care is needed, however. In areas of nuclear families, inequality is easily identified by the institution of wills and testaments to define the final holder of the family property. In these areas, one child tends to inherit at the expense of his or her siblings. Families 
that combine inequality and liberalism are called 'absolute' nuclear by Todd (1990a). In the remaining areas of nuclear families, wills and testaments are unnecessary, as children, at least sons, inherit equally. This 'egalitarian nuclear' system encourages the persistence of slightly stronger relations among children until the inheritance is completely divided after the parents' death (Todd, 1990a: 37-38).

Wills and testaments are also unnecessary in areas dominated by authoritarian stem families as the property is passed by strength of tradition to the eldest son, resulting in an institutionalized system of inequality. Todd explains that this is the case in all stem family areas, despite the fact that often laws state that all children should inherit equally. Todd (1990a) claims that in these latter areas, classified as being dominated by 'incomplete' stem families, the strength of the primogeniture tradition tends to override any such egalitarian law-making. Finally, Todd terms a further category of family 'communitarian', where both familial authority and equality are strong. In areas dominated by this family type, married brothers remain living and working in the family home, under the authority of their father, but with the expectation of an equal inheritance.

Table 1 summarizes the interaction between the equality and the authority dimension while Table 2 provides a summary of the main characteristics of these five family types that emerge.

Importantly, Todd's data is only available on a map (see Figure A1 in Appendix 1 for a translated version of Todd's map) and he derives his conclusions from a simple visual comparison between his map of family structure and a series of economic, 
Table 1. Family types defined by authority and equality

\begin{tabular}{|l|l|l|}
\hline Strong authority & Egalitarian & Non-egalitarian \\
\hline Weak authority & Communitarian & $\begin{array}{l}\text { Stem (whether of an } \\
\text { 'absolute' or 'incomplete' } \\
\text { nature) }\end{array}$ \\
\hline Egalitarian nuclear & Absolute nuclear \\
\hline
\end{tabular}

Table 2. Main characteristics of family types

\begin{tabular}{|l|l|}
\hline Family type & Main characteristics \\
\hline Absolute nuclear & $\begin{array}{l}\text { Total emancipation of children in adulthood to form } \\
\text { independent families made simply of a couple and their } \\
\text { children. Division of inheritance among children by testament } \\
\text { or will, usually to a single individual, often the son. Brothers } \\
\text { and sisters are treated as independent individuals (Todd, } \\
\text { 1990a: 37). }\end{array}$ \\
\hline Egalitarian nuclear & $\begin{array}{l}\text { Total emancipation of children in adulthood to form } \\
\text { independent families made simply of a couple and their } \\
\text { children. Equal division of inheritance among children. This } \\
\text { system encourages the persistence of slightly stronger } \\
\text { relations between parents and children until the inheritance is } \\
\text { completely divided after the parents death (Todd, 1990a: 37- } \\
\text { 38). }\end{array}$ \\
\hline Stem family & $\begin{array}{l}\text { Extended families with several generations living under one } \\
\text { roof. One child - generally, but not always, the eldest - } \\
\text { marries and has children that remain in the household in order } \\
\text { to preserve the lineage. The rest have the choice of remaining } \\
\text { unmarried within the household or of marrying and leaving } \\
\text { the home or becoming soldiers or priests. The house and the } \\
\text { land are inherited by the son who stays at home. Others may } \\
\text { receive some financial compensation. The inheriting son, who } \\
\text { stays at home, remains under the formal authority of the father } \\
\text { (Todd, 1990a: 38). }\end{array}$ \\
\hline $\begin{array}{l}\text { Incomplete } \\
\text { family }\end{array}$ & $\begin{array}{l}\text { As above, but with more egalitarian inheritance rules (in } \\
\text { principle, but rarely in practice). }\end{array}$ \\
\hline family & $\begin{array}{l}\text { Extended family in which all sons can get married and bring } \\
\text { their wives to the family home. Equality among children in } \\
\text { inheritance, with family wealth and estates divided after the } \\
\text { death of parent (although a period of cohabitation between } \\
\text { married brothers after the death of the parents is possible) } \\
\text { (Todd, 1990a: 39-40). }\end{array}$ \\
\hline
\end{tabular}


political, and social maps of Europe. Furthermore, the regions used by Todd (1990a) are often outdated administrative units. In some cases, like France, these units roughly correspond to current administrative divisions (even though a few French departments have been created in the last forty years) and are being used today by Eurostat (the main data provider at the European level) for other variables. In other cases, such as the UK, the administrative map of Todd (1990a) differs quite significantly from the current regional map. To retrieve Todd's data on family structure, we first digitized his main summary map of family structures in Europe (1990a: 74). Then using GIS software (ArcInfo), we overlaid NUTS III European regions. These are the smallest regions at which data are broadly available in Europe. This operation required a careful adjustment of Todd's original map which does not appear to have been generated by any standard projection. We then used ArcInfo to read for each NUTS III region which proportion of its area was attributed to each family type. At the NUTS III level (1031 regions for 14 countries), a large majority of regions are homogenous according to Todd's classification. We also made two small corrections to Todd's data. His original map puts the French region of Languedoc and the Spanish regions of Andalucía as indeterminate. However, his text indicates that Languedoc should be classified as incomplete stem and Andalucía as nuclear egalitarian. ${ }^{1}$ Finally, given the paucity of European data at the NUTS III level, we aggregated our data at the NUTS II level (where NUTS III regions were weighted proportionately to their land area).

\footnotetext{
${ }^{1}$ Our results are not sensitive to these two minor changes.
} 
Figure 1 represents a mapped version of our final output ${ }^{2}$. It presents the geographic spread of the family types identified by Todd over Europe. It also shows a sixth category, 'indeterminate', where information is unavailable or where family types do not conform to the other categories, or where no single category dominates. As the map indicates, the absolute nuclear family was dominant in southern and eastern England, eastern Scotland, north west France, Holland and other coastal regions of the Netherlands, Denmark, and southern Norway. The absolute stem family prevailed in the west of the British Isles, northern Spain, south western France, much of Germany, Austria, and German-speaking Switzerland, as well as much of southern Sweden and coastal Finland. Egalitarian nuclear families were strongest in northern and eastern France, most of Spain, and southern and north-western Italy. As Todd has noted, the areas dominated by incomplete stem families lie on the borders between complete stem and egalitarian nuclear families, reflecting their mixture of egalitarian law, and non-egalitarian practices. These cover Belgium, Luxembourg, and large areas of the upper Rhine valley between Germany and France, as well as the regions of PoitouCharentes and Gironde in western France and Veneto and Trento in Italy. Communitarian families are relatively uncommon, occupying areas of central Italy and large parts of the interior of Finland.

\footnotetext{
${ }^{2}$ In order to create the adapted map presented in Figure 1, the following boundary datasets were used:

- Continental Europe and Ireland: ESRI (2004). 'Europe Basemap: Level 1 and 2 Provinces'. In: ESRI Data \& Maps-World, Europe, Canada, and Mexico (Level 1: Sweden, Luxemburg, Norway, Denmark, Netherlands, Austria; Level 2: Finland, Portugal, Ireland, Belgium, Switzerland, France, Germany, Italy, Spain).

- UK: Edina UKBORDERS (2004). English and Welsh Counties and Scottish Regions for 1981 This is based on data provided through EDINA UKBORDERS with the support of the ESRC and JISC and uses boundary material (copyright of the Crown).

- NUTS Regions in the EU: GISCO (2003). "Administrative/NUTS Regions: NUEC1MV7'. In: EU Boundaries CD Rom. Version 1.
} 
Note that this map does not necessarily present current information. As already highlighted, some of these patterns seem to reflect very old historical divisions. Beyond the Etruscan and Celtic areas mentioned above, it is hard not to notice that regions where equality among siblings is prevalent tend to be core regions of the Western Roman Empire. In particular the border between equality and inequality in Northern France (which, interestingly, does not correspond to the French-Belgian border) closely approximates the historical border between French and Flemishspeaking (or, for that sake, between Latin and Germanic-speaking) populations which dates back to Roman times. Importantly, this map of family structure does not appear to reflect an opposition between Northern and Southern Europe. Communitarian families are heavily concentrated in a few areas, whereas stem and nuclear families can be found nearly everywhere. Even more importantly, these family divisions do not coincide with national borders and most countries exhibit a high level of heterogeneity. France, for instance, contains nearly all types of families and no country considered in the analysis (except for Luxembourg) is entirely homogenous. This means that we will be able to identify the effects of medieval family structure and condition out national effects. This is important because even though family types do not solely reflect a North-South opposition (or any other geographic distinction), there might be some correlation between countries and family types (where, for instance, stem families seem to be over-represented in Northern Europe). 


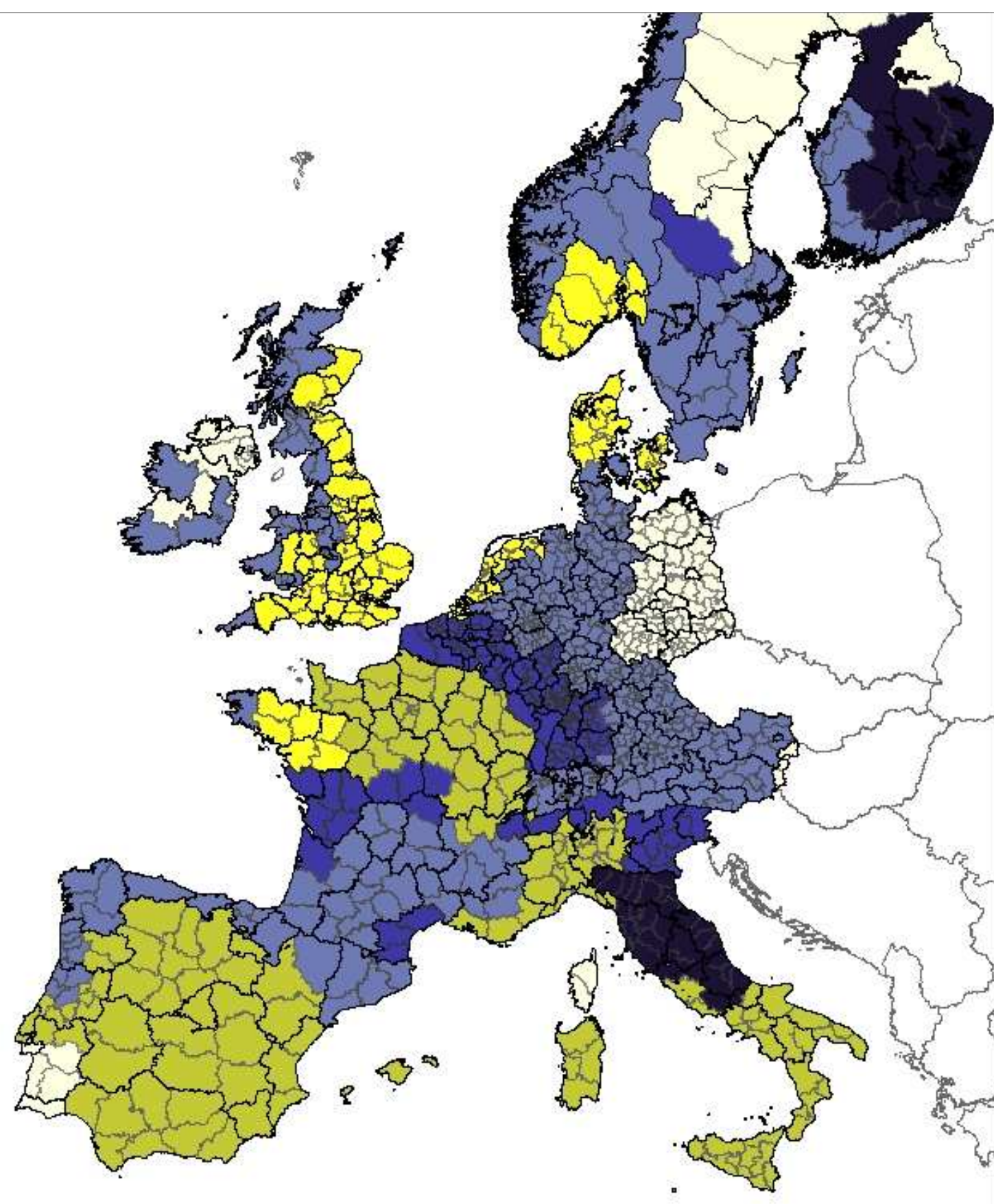

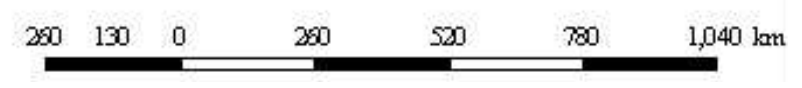

Figure 1. Family types in Europe. 


\section{The persistence of family types and their economic significance}

Although our information on family and kinship links and inheritance customs dates back, at least, to the Middle Ages, an underlying assumption of both Todd's and our work is that these family types persist in some way to the present day. This persistence maybe direct, evidenced today perhaps by the relatively late age at which the offspring of Mediterranean families leave home compared to their northern European equivalents (Reher, 1998: 205). This form of persistence seems intuitively likely given the probability that children are brought up to consider their family traditions as proper and so recreate them with their own children. Alternatively, the persistence may develop through intermediate factors, such as the nature of political or economic institutions, shaped first by family structures and which, in turn, have continued to influence our society today in a path-dependant manner.

However, a broad range of academic work in a variety of different fields either argues against these hypotheses or otherwise assumes that the persistence of family structures, whether direct or indirect, is not significant. For example, some of the most influential work on social capital, such as that of James Coleman $(1988,1990)$, assumes that highly developed social capital is a replacement for family structures which, as a result, have become an irrelevance. In this view, social capital is seen as more modern and beneficial than family structures and, once established, allows traditional family structures to wither away. Those who have studied the variety and influence of different family types have also used the idea of modernity and superseding institutions within the analysis of family types themselves. For example, Greif $(2005,2006)$ argues that nuclear families superseded other 'kinship' forms of 
family structure as part of the modernization process throughout Europe, suggesting that while nuclear family types encouraged industrialization, so too did industrialization help to bring an end to non-nuclear forms of family (Greif, 2005: 3). ${ }^{3}$

Overall, then, the idea that family types or institutions persist has been challenged in three different ways, each a description of one type of institution superseding another, as summarized in Table 3:

Table 3. Superseding institutions

\begin{tabular}{|l|l|l|}
\hline Original institution & Superseding institution & Associated authors \\
\hline Family & Social Capital & James Coleman $(1988,1990)$ \\
\hline Community & Society & Max Weber (1921) \\
\hline Kinship families & Nuclear families & Avner Greif (2005) \\
\hline
\end{tabular}

Demographers, however, are less confident that nuclear families have spread so rapidly as a result of industrialization, and, indeed, regard this view as something of a myth. Scott Smith (1993), for example, claims that demographers have argued consistently that the most notable thing about family structures was not their changing, but their constancy over centuries. He notes that economists as far back as Alfred Marshall and Adam Smith have used family structure to help explain disparities in economic growth and development (Scott Smith, 1993: 7), while pointing out that few demographers have disagreed with them since. Anstone et al (1999) also criticize those who have written about social capital without paying attention to the work of demographers, remarking directly on the work of Coleman, for example:

\footnotetext{
${ }^{3}$ Indeed, Greif argues that the domination of Europe by the nuclear family was underway as early as the $8^{\text {th }}$ century (Greif, 2005: 3).
} 
“We disagree with Coleman's assessment of the declining importance of the family in industrialized societies, and we argue that family formation is among the most important types of investment in social capital made in all societies. On this basis we contend that sociologists and other social scientists interested in social capital would do well to attend to the substantive findings of family demographers." (Anstone et al 1999: 5)

The essence of the demographers' approach, as expressed by Anstone et al (1999) is that family structure is the origin and shaper of social capital and is built upon rather than superseded. Family structures may become internalized and reproduce themselves through communitarian interpersonal networks (Portes, 1998), for example, or through repeated behavior within communities that ends up embedding cultural norms and values, leaving an indelible imprint across society (Hofstede, 1980). Reher (1998) describes how family structures might directly reproduce themselves, even in the face of significant social upheaval:

"Regardless of their historical origins, attitudes toward the family and the individual make up the cultural tapestry of societies, and thus they are models that are learned at a very young age and that societies - individuals, families, institutions - help perpetuate. Learning these behaviour patterns is the cornerstone of the socialization of children. They are attitudes shared by the society as a whole. Perhaps because of this, they have been so resistant to the otherwise corrosive effects of economic, political, social and demographic modernization. Even though the changes of this past century have tended to make cultures and mentalities more uniform, they have done little to erase the historic profiles of family systems in Europe" (Reher, 1998: 215) ${ }^{4}$

If the differences between family structures that were identified by Todd do indeed persist to the present then they may have a variety of economic impacts, which may

\footnotetext{
${ }^{4}$ Reher goes on to argue that while the historical persistence of family structures is significant, the distinctions between stem and nuclear, and egalitarian and hierarchical are unnecessary. Instead, a simpler distinction between weak family ties in northern Europe and strong family ties in southern Europe is all that is deemed necessary to explain the significant differences between the two areas (Reher, 1998: 221). As will be seen, our results have some bearing on this debate.
} 
help to explain current regional disparities and the difficulties of reducing them. Both Todd (1990a, 1990b,) and Greif (2005) have attributed to family structures an extremely influential role in the European industrial revolutions and subsequent economic growth. For example, it has been argued that the relative independence of the children of nuclear families, and their habit of leaving home early in pursuit of economic opportunities, made them a far more likely proletarian workforce compared to the offspring of communitarian or stem families. The latter were much less inclined to move away from the family to new cities or factories and may have thus favored the persistence of agricultural practices (Todd, 1991: 38). The lack of any future inheritance for the majority of children in inegalitarian family areas may have also spurred the need to educate and train, in contrast to regions with more egalitarian traditions. Todd uses this argument as part of his explanation of how the absolute nuclear dominated north western part of France adapted to the crises of heavy industry in the 1970s by shifting to different types of production, more effectively than other areas of France (1991: 144). This ability is seen as a reflection of the dynamism and adaptability engendered by the independence and drive of those brought up within the absolute nuclear tradition. In general, the increased mobility of people in absolute nuclear dominated areas could also be used to help explain either greater entrepreneurial capacity or lower levels of structural unemployment.

On the other hand, the significance of family structures in the much-discussed success of interlinked small family firms in the Third Italy (Becattini, 1987; Storper, 1997: 137-146), for example, offers one way in which close knit, communitarian family structures can hold advantages over looser, nuclear family types. Stem families, too, may have some advantages in certain economic and historical conditions. The inbuilt 
inequality associated with this family structure may lead to concentrations of capital or land that would facilitate, or create the appropriate incentives for, the investment required for leaps in industrial development. It could also be argued that, while the offspring of nuclear families are more mobile, the offspring of stem families are more likely to work efficiently within the authoritarian labor systems of mass production. Overall, these various advantages and disadvantages of family types in terms of their suitability for various types of economic development may make it possible to construct a historical narrative in which different family types turn out to be more efficient at different times. While stem family dominated areas maybe to the fore in times of industrial mass production, nuclear family dominated areas may be better off when, as now, an economic context calls for adaptability and entrepreneurialism.

As suggested above, however, the influence of family structures might also persist through intermediate factors, even if the original nature of the family has since changed (perhaps, for example, becoming homogenously nuclear throughout Europe, in Greif's (2005) view). For example, it might initially be argued, following Greif (2005), that nuclear family dominated regions were more likely to develop formal associations, or 'corporations', whereas stem family dominated areas were prone to informal community type institutions within which transactions and agreements were framed. It might then be hypothesized that even if the nuclear family type spread across Europe, superseding all other types of family, the institutions that had originally been shaped in different ways by family structures had become resistant to further change, persisted to the present day and so continue to shape economic outcomes. 
We return to discuss these and other theories more thoroughly in the light of our results, below. This paper does not claim to address the question of whether family structures persist directly or indirectly through intermediate factors. Our hypothesis and results simply address the question of whether or not the influence of family structures persists in some way. Neither do we address whether family types are the primary cause or symptoms (or a first order outcome) of deeper historical, cultural or even geographical determinants that might shape either the nature of family structures themselves, or both family structure and other effects correlated with it. For example, even if links were confirmed between nuclear families and higher levels of social capital, the correlation might be the result of a shared, fundamental cause, such as levels of assimilation into the Roman Empire, or the practice of certain pre-Christian religions, rather than any direct causal relationship between the variables. Further analysis in this area can be found in the work of Mamadouh (1999) or Tabellini (2005), while the nature of the potential causative links between the variables is discussed in more detail in the results section, below.

\section{The model}

Our starting hypothesis is that medieval family types - either directly, through their survival over time, or indirectly, through their internalization in values, customs, and culture - are strongly associated with current regional disparities across Europe in the areas we are considering. The disparities in question have dictated our dependent variables and fall into several categories. We study demographic data in terms of average family size in 2000 and also with regard to educational attainment, measured by the percentages of the population with education up to primary and beyond 
secondary level in 1997. We also measure labor force participation in terms of overall and female employment; social capital in terms of memberships of clubs and the percentage of people who meet with friends at least once a week; and sectoral structure by using the percentages of employment in manufacturing and services. Finally, we examine economic conditions and performance using GDP per capita in 2004, GDP growth between 1975 and 2004 and inequality as measured by Gini coefficients in 2004 (Table 4). These variables have been selected as a result of their potential relevance to current debates surrounding regional disparities in Europe. By selecting a wide range of indicators, representing demographic, social, and economic fields of study we hope to offer a set of similarly broad conclusions, while identifying which factors are affected by which aspects of family type.

Table 4: Dependent variables and sources

\begin{tabular}{|c|c|c|c|}
\hline Factor & Variable & Source & \\
\hline $\begin{array}{l}\text { Demographic } \\
\text { structure }\end{array}$ & $\begin{array}{l}\text { Average household size } \\
\text { in } 2000, \text { measured in } \\
\text { number of individuals per } \\
\text { household }\end{array}$ & $\begin{array}{ll}\text { European } \\
\text { Community } \\
\text { Household } \\
(\text { ECHP) }\end{array}$ & Panel \\
\hline $\begin{array}{l}\text { Educational } \\
\text { attainment }\end{array}$ & $\begin{array}{l}\text { - Percentage of the } \\
\text { population with education } \\
\text { beyond secondary level } \\
\text { in } 1997\end{array}$ & - EUROSTAT & \\
\hline $\begin{array}{l}\text { Labor force } \\
\text { participation }\end{array}$ & $\begin{array}{l}\text { Employment levels in } \\
\text { 2003, as a percentage of } \\
\text { the total adult population } \\
\text { - Female participation in } \\
\text { 2003, as a percentage of } \\
\text { the total adult population }\end{array}$ & $\begin{array}{l}\text { - } \text { EUROSTAT } \\
\text { - EUROSTAT }\end{array}$ & \\
\hline Social capital & $\begin{array}{l}\text { - Membership of clubs in } \\
\text { 2000, as a percentage of } \\
\text { the population included } \\
\text { in the sample } \\
\text { - Percentage of people who } \\
\text { meet with friends at least } \\
\text { once a week in } 2000, \text { as a } \\
\text { percentage of the } \\
\text { population included in } \\
\text { the sample }\end{array}$ & - ECHP & \\
\hline
\end{tabular}




\begin{tabular}{|l|l|l|}
\hline Sectoral structure & $\bullet \begin{array}{l}\text { Percentage of } \\
\text { employment in } \\
\text { manufacturing in 2003 }\end{array}$ & $\bullet$ EUROSTAT \\
& $\begin{array}{l}\text { Percentage of } \\
\text { employment in services } \\
\text { in 2003 }\end{array}$ & $\bullet$ EUROSTAT \\
\hline $\begin{array}{l}\text { Economic } \\
\text { performance }\end{array}$ & $\begin{array}{l}\text { GDP per head in 2004, } \\
\text { measured in constant } \\
\text { Euros (base 1995) }\end{array}$ & $\begin{array}{l}\text { Personal Gini coefficient, } \\
\text { measuring inequality in } \\
\text { income per capita in 2000 }\end{array}$ \\
$\qquad \begin{array}{l}\text { Growth of GDP per } \\
\text { capita 1975-2004, } \\
\text { measured in constant } \\
\text { Euros (base 1995) }\end{array}$ & $\bullet$ Cambridge \\
\hline
\end{tabular}

Our simple OLS model adopts the following form:

$y=\alpha+\beta_{1} F_{i}+\beta_{2} N D_{i}+\varepsilon_{\mathrm{i}}$

where:

$y$ represents the dependent variables included in Table 4;

$F_{i}$ is the dominant family type in region i. Six family types corresponding to Todd's classification as described above are used:

F1: Absolute nuclear

F2: Egalitarian nuclear

F3: Stem family

F4: Incomplete stem family

F5: Communitarian family

F6: Undetermined family types;

$N D_{i}$ are national dummies, used to capture the effect of nationally defined factors on the dependent variables. F1, the absolute nuclear family and France are used as the family type and country of reference, and therefore not included in the regression analysis. All coefficients then can be interpreted as relative to the family type and 
country of reference. ${ }^{5}$ Finally $\beta_{1}$ and $\beta_{2}$ are the regression coefficients and $\varepsilon$ is the error term.

The territorial unit of analysis is made of 190 European NUTS II regions. Note that the national dummies play an important role in this regression. On the one hand, they ensure that the coefficient on family types does not pick up national effects. On the other hand, they capture the effects of family types to the extent that a dominant family type in a country will affect the outcomes for this country through for instance its national institutions. In this respect, Todd (1990b) argues that French institutions tend to reflect nuclear egalitarian values that come from the greater Paris region. This implies that our coefficients on family types probably under-estimate the association between family types and regional outcomes.

The results of the analysis are presented in Table $5^{6}$.

\footnotetext{
${ }^{5}$ The choice of the absolute nuclear family as our base category, is motivated by a) the general belief that nuclear types are now the dominant forms of family structure (Greif, 2005 and 2006) and b) by the perception of absolute families as the most adequate family structure for the promotion of innovation, adaptability, and economic progress (Todd, 1991; Greif, 2005).

${ }^{6} \mathrm{We}$ do not control for spatial autocorrelation, as it is unclear, from a theoretical perspective, whether we could expect spillovers in this case. Were we to find some positive effects of the neighboring regions' family types on regional performance, it is unlikely that family types would be the key factor behind that spatial dependency, as they could be masking other factors, such as market potential effects. In any case, the risk of spatial dependence in this case is either limited in space (Rodríguez-Pose and Crescenzi, 2008) and can be regarded as a secondary concern in comparison with specification issues (Briant et al., 2008).
} 


\begin{tabular}{|c|c|c|c|c|c|c|}
\hline Family types & $\begin{array}{l}\text { Average household } \\
\text { size }\end{array}$ & $\begin{array}{l}\text { Education beyond } \\
\text { secondary level }\end{array}$ & $\begin{array}{l}\text { Percentage } \\
\text { working in total } \\
\text { population }\end{array}$ & $\begin{array}{l}\text { Ratio of women to } \\
\text { men in working } \\
\text { population }\end{array}$ & Membership of clubs & $\begin{array}{l}\text { Meeting friends once } \\
\text { a week }\end{array}$ \\
\hline \multirow[t]{2}{*}{ Egalitarian nuclear } & $0.157 *$ & $-3.289 *$ & $-0.022 *$ & $-0.038^{*}$ & $-0.065 * * *$ & -0.007 \\
\hline & 0.084 & 1.778 & 0.012 & 0.022 & 0.017 & 0.024 \\
\hline \multirow{2}{*}{ Stem } & 0.011 & $-2.545 * *$ & $-0.015^{*}$ & 0.003 & $-0.025 * *$ & 0.022 \\
\hline & 0.058 & 1.237 & 0.008 & 0.015 & 0.012 & 0.016 \\
\hline \multirow[t]{2}{*}{ Incomplete stem } & $0.196 * *$ & $-4.468 * *$ & -0.008 & -0.009 & 0.010 & 0.031 \\
\hline & 0.086 & 1.832 & 0.0125 & 0.023 & 0.018 & 0.025 \\
\hline \multirow[t]{2}{*}{ Communitarian } & 0.061 & -3.147 & -0.007 & 0.038 & -0.042 & 0.028 \\
\hline & 0.127 & 2.536 & 0.017 & 0.031 & 0.026 & 0.036 \\
\hline \multirow[t]{2}{*}{ Undetermined } & 0.062 & 1.132 & $-0.046^{* * *} *$ & 0.017 & $-0.064 * * *$ & -0.129 *** \\
\hline & 0.083 & 1.683 & 0.011 & 0.021 & 0.017 & 0.024 \\
\hline National dummies & Included & Included & Included & Included & Included & Included \\
\hline $\mathrm{df}$ & 15,151 & 17,171 & 18,171 & 18,171 & 15,151 & 15,151 \\
\hline Number of obs & 167 & 189 & 190 & 190 & 167 & 167 \\
\hline $\mathrm{F}$ & 32.76 & 23.22 & 16.92 & 22.74 & 85.59 & 136.65 \\
\hline R-squared & 0.77 & 0.70 & 0.64 & 0.71 & 0.89 & 0.93 \\
\hline Adj R-squared & 0.74 & 0.67 & 0.60 & 0.67 & 0.88 & 0.92 \\
\hline
\end{tabular}

\begin{tabular}{|c|c|c|c|c|c|}
\hline Family types & $\begin{array}{l}\text { Employment in } \\
\text { manufacturing }\end{array}$ & Employment in services & GDP per capita & Personal gini coefficient & $\begin{array}{l}\text { Growth of GDP (1975- } \\
\text { 2004) }\end{array}$ \\
\hline \multirow[t]{2}{*}{ Egalitarian nuclear } & 0.031 & -0.041 & $-5122.8 * * *$ & 0.002 & $-0.295^{*}$ \\
\hline & 0.024 & 0.027 & 1910.5 & 0.014 & 0.204 \\
\hline \multirow[t]{2}{*}{ Stem } & $0.029 *$ & $-0.036^{*}$ & $-2848.4 * *$ & -0.005 & $-0.249 *$ \\
\hline & 0.017 & 0.019 & 1329.3 & 0.009 & 0.142 \\
\hline \multirow[t]{2}{*}{ Incomplete stem } & $0.0765 * * *$ & $-0.074 * * *$ & $-3981.7 * *$ & $-0.024 *$ & $-0.455^{* * *}$ \\
\hline & 0.0245 & 0.028 & 1968.2 & 0.014 & 0.211 \\
\hline \multirow[t]{2}{*}{ Communitarian } & $0.114 * * *$ & $-0.110 * * *$ & $-5172.9 *$ & $-0.040 * *$ & -0.060 \\
\hline & 0.034 & 0.039 & 2724.5 & 0.021 & 0.292 \\
\hline \multirow[t]{2}{*}{ Undetermined } & -0.004 & -0.005 & $-9380.0 * * *$ & $-0.070 * * *$ & $-0.515^{* *}$ \\
\hline & 0.023 & 0.026 & 1807.8 & 0.013 & 0.237 \\
\hline National dummies & Included & Included & Included & Included & Included \\
\hline df & 17,170 & 17,170 & 18,171 & 15,151 & 18,162 \\
\hline Number of obs & 188 & 188 & 190 & 167 & 181 \\
\hline $\mathrm{F}$ & 3.67 & 6.27 & 11.63 & 35.02 & 18.85 \\
\hline R-squared & 0.27 & 0.39 & 0.55 & 0.78 & 0.68 \\
\hline Adj R-squared & 0.20 & 0.32 & 0.50 & 0.75 & 0.64 \\
\hline
\end{tabular}

Notes:

Coefficients relative to those of absolute nuclear families

Standard errors in italics below coefficients

$* * *, * * *$ denote significance at the 1,5 , and $10 \%$ level respectively

Table 5. Summary of Results 


\section{Family types and regional disparities in Europe}

The main result that emerges from Table 5 is the favorable position of absolute nuclear families, in comparison to all of the other five family types, with regard to current levels of GDP. Areas where absolute nuclear families dominate, or have dominated in the past, also have higher levels of inequality than regions of stem incomplete, communitarian, or indeterminate family type traditions (although the difference with either egalitarian nuclear or absolute stem family areas is not statistically significant). Recent growth in GDP has also been higher in absolute nuclear areas compared to both types of stem family, egalitarian nuclear, and indeterminate areas, but not compared to communitarian regions. The employment data also provides some striking differences. Once again, absolute nuclear families show better results than three other types of areas (those dominated by egalitarian nuclear, absolute stem, and undetermined families), while showing no difference with either communitarian or incomplete stem areas.

There appears to be a clear dividing line between nuclear families, on the one hand, and stem and communitarian families, on the other, with regard to employment. Employment in nuclear family dominated areas is more likely to be in services, while employment in stem or communitarian areas is more strongly linked to manufacturing. One social capital indicator is notable, showing that the people in egalitarian nuclear, absolute stem, and indeterminate family areas are less likely to have joined clubs or associations. The other social capital indicator is notable only in that our national dummies appear to be of much greater relevance than family type. Finally, demographic and educational data also isolates absolute nuclear family areas. 
These areas typically have smaller households than egalitarian nuclear or stem incomplete family areas, and have a greater proportion of people educated to university level than absolute nuclear families, while communitarian and indeterminate areas are similar to absolute nuclear families with regard to both indicators.

In general, our results appear to confirm that medieval family types in Europe have a significant and strong association with current regional disparities in household size, educational attainment, social capital, labor participation, sectoral structure, as well as with wealth and inequality. There are four main causal paths which could potentially account for these associations. First, family structures might persist to the present and continue to directly affect economic outcomes. Second, family structures may have caused changes in the past to other institutions, which in turn have caused the current disparities we observe today. Third, reverse causation is also plausible: that differences in economic and institutional factors across regions have themselves caused the variation in family structures. The fact that the industrial revolution took place first in England, for example, may have caused that country's families to establish, or strengthen its 'nuclear' traditions. It would also be a simple matter to combine these two directions of causation within hypotheses based on bi-directional, or circular causation. Fourth, as mentioned above, a further possibility is that family structures are merely an outcome of a deeper, underlying determinant (such as religion or culture), which might represent the true cause of the variations we observe. In this case, family structures would be endogenous to the causal process and of little explanatory value. The first two types of causation described above are the main focus of the analysis below, with discussion of reverse and circular causation where 
relevant. However, proving or eliminating the fourth possibility, by establishing empirically if both family structures and its correlates are outcomes of some other common cause, would require further testing and, while it may be the subject of a future paper, it is beyond the scope of this one.

Theories regarding similar associations between family structures and economic and social indicators have already been investigated by Todd (1990a, 1990b, 1991), and those who have followed him (Mamadouh, 1999; Schultenover, 1999; Berry, 2000) and provide a framework within which our own hypotheses can be developed. The persistence in Europe of family structures throughout the last two millennia has been used in the past to help explain, for example, the relative levels of welcome or resistance to tides of change such as Protestantism and secularism (Todd, 1990a and 1990b; Schultenover, 1999), political culture in general (Todd, 1990a and 1990b; Mamadouh, 1999), and specifically economic processes such as industrialization and modernization (Todd 1990a, 1990b). Some of these theories have already been mentioned in section 3 above and offer an excellent starting point for much of our analysis.

Our clearest and most significant results appear to suggest that areas dominated by absolute nuclear families generally enjoy an advantage in terms of GDP per capita over every other type of region. Once the national effect is controlled for, regions with an absolute nuclear family tradition had in 2004 a GDP per head which was on average close to 3,000 euros higher than in areas with a stem family tradition; close to 4,000 euros higher than in incomplete stem regions; more than 5,000 euros higher than in egalitarian nuclear or a communitarian dominated areas; and more than 9,000 
euros than in indeterminate areas (Table 5). These regions have also enjoyed better recent GDP growth compared to stem family dominated areas. Between 1975 and 2004 the growth of GDP per capita in areas with a tradition of absolute nuclear families outstripped that of egalitarian nuclear, stem, and indeterminate family traditions by between 13 and 15 per cent, and that of incomplete stem family types by close to 20 per cent. Only communitarian family tradition areas kept up with absolute nuclear areas in terms of recent economic growth (Table 5). It would be tempting to draw some simple conclusions regarding this correlation, and argue that the absolute nuclear family structure is better suited to economic development. However, one need only reflect on the difficulty of defending this position in the late 1970s, when the UK was considered the 'sick man of Europe' despite the dominance of the absolute nuclear family form, to understand that no such simple conclusion is available. Different countries have led European economic development at different times, and at no time since the 1870 s has it been possible to argue that the stem family dominated area of Germany, for example, has been economically backward.

It is possible to build a more subtle and powerful explanation of how family types may influence economic development, using some of the arguments already described in section 2.1 above. First, the nuclear family's tradition of emancipation increases potential for movement away from the family home which can facilitate the pursuit of independent economic opportunities. Second, the inability to rely on the family for income and housing could be said to generate a more entrepreneurial spirit of selfreliance, as well as greater motivation to work. Third, in absolute nuclear families, the principles of primogeniture may exaggerate these first two tendencies still further, as non-inheriting children are left even more reliant on their own initiative. As a result, 
we would expect the offspring of absolute nuclear families to move further, faster, and take greater risks in order to take advantage of economic opportunities, especially in times of structural economic adjustment.

To take a concrete example of this type of argument, let us consider Todd's analysis of the stark economic and sectoral divides within France (Todd, 1991: 38). He argues that, in the $19^{\text {th }}$ century, the creation of an industrial workforce was only possible in the nuclear family dominated north, as the offspring of southern stem families were unwilling to uproot themselves away from the family home to work in urban factories. Todd also suggests that the difference between egalitarian nuclear and absolute nuclear families may account for the differences in economic dynamism between north eastern and north western France, as western Europe adjusted from manufacturing to service economies in the later $20^{\text {th }}$ century. He argues that the current areas of decline and structural unemployment in egalitarian nuclear north eastern France compare unfavorably to the dynamism and flexibility of both north western France and England, where the economy has adjusted more successfully. The lack of adaptability and dynamism, it is argued, is related to the relative lack of pressure on the offspring of egalitarian families, due to their expectations of inheritance. The statistically significant correlations between absolute nuclear families and GDP, recent growth and inequality would all appear to support these interpretations.

Our results concerning the proportion of the working population in the industrial and service sectors demonstrate what appears to be a clear dividing line between stem and communitarian families, on the one hand, and nuclear families, on the other. While in 
2003 communitarian family dominated areas had a share of employment in manufacturing that was more than 11 points higher than in absolute nuclear family type regions and incomplete stem and stem areas were 7.6 and 3 points higher, respectively, than absolute nuclear areas, the roles were reversed when employment in services was considered. In this category, the differences were of 3.6 points with respect to stem family areas, 7.3 with respect to incomplete stem, and 11 points with respect to communitarian family dominated regions, always in favor of absolute nuclear regions (Table 5). Given the hypothesis that absolute nuclear families should be more able to adapt to new economic structures, we would expect these regions to reflect a more modern sectoral balance, which very much appears to be the case. It could be argued that the nuclear areas industrialized first, grew faster and are now further along the path of modernization having transformed more quickly and fully into service societies. However, while the absolute nuclear dominated UK did indeed industrialize first, there are many instances of stem dominated areas industrializing before other absolute nuclear areas and it would therefore be unwise to attribute industrial take-off or economic development in general, solely to family structure.

A finer version of this story could be developed by returning to the discussion regarding dynamism, flexibility, and entrepreneurialism. Rather than simply being 'further ahead', the offspring of absolute nuclear families, being less dependent on their families and more entrepreneurial in spirit, are more likely to be able to adapt, move or change in response to any given economic change or sectoral shift. That is to acknowledge that, while many factors exogenous to family structure are likely to be the cause of major economic changes, family structure itself may be a key determinant of the ability to adapt to those changes. Having made a similar argument 
about north western and north eastern France, Todd adds (1991: 150) that areas where the numbers working in services increased also saw increases in the numbers working in industry, too. This would appear to strengthen our interpretation that absolute nuclear areas may simply be more adaptable regardless of the circumstances, rather than merely 'ahead' in terms of the transition from industry to service based economies.

The advantage of this view is that it takes account of the obvious fact that other factors apart from family structure may produce economic change. That is to say that even when family structure is not the fundamental cause of change, it can determine how a region might react to a wave of change caused by something else. A key part of this adaptability may lie in the availability and nature of social capital, and here again our results can be used to support our general hypothesis. The results in Table 5 suggest that the offspring of absolute nuclear families are amongst the most likely to form associations and join clubs. One possible reason for this is that they are less able to depend on their families for support and so must form other networks in order to compensate. As these are built amongst people who do not necessarily have kinship ties, they have both greater potential for expansion, and are also more likely to have formal rules and hence greater transparency. As a result, they may be more efficient and conducive to growth. Greif (2005) suggests something closely related to this when describing how nuclear families, in medieval times, facilitated the establishment and growth of what he calls "corporations ${ }^{\text {,7 }}$

\footnotetext{
${ }^{7}$ Defined as "intentionally created, voluntary, interest-based, and self-governed permanent institutions" (Greif, 2005: 1)
} 
For an individual, corporations reduce the benefits from belonging to a kinship group [non-nuclear family structure] while a nuclear family increases the benefits from being a member of a corporation (Greif 2005: 1-2)

Thus, Greif presents a virtuous circle whereby causation works in both directions nuclear families providing encouragement for the establishment of corporations, and the related economic and social transformation encouraging the domination of the nuclear family across Europe. Greif goes on to reflect that nuclear families seem to encourage both flexibility and independence, and that societal institutions are developed in part as a response to the lack of safety net or associational benefits that are provided by non-nuclear family types. The growth of corporations is then used to help explain why the British monarchy had its influence limited, and the interests of the merchant class began to have more significance. This is a familiar argument and reminiscent of Acemoglu et al's $(2001,2005)$ view of economic and political development. The link between nuclear families, the lack of informal social safety nets, and the rise of compensating institutions is also supported by accounts of the birth of the welfare state in the UK. Richard Smith (1996) traces the history of the welfare state back to the Poor Laws of 1601, which was revised and reformed throughout it 400 subsequent year history, and argues that its existence owed much to the structure of English families, which we define here as 'nuclear'.

However, the plausibility of reverse causation, suggested by Greif's account, whereby the modern economy acts to spread the prevalence of the nuclear family, requires further attention. While Greif's argument proposes that causation runs both ways, it could be argued that the most significant causal explanations of the correlations described here between family structure types and economic changes and disparities 
are those that run from the latter to the former. If this were the case, then much of the explanation in the pages above would lose its value. For example, the correlation between nuclear families and early participation in the industrial revolution may be the result of the industrial revolution pulling children away from families at an earlier age, and encouraging them to travel further. This version of the causative link might see the existence of stem family dominated areas in western Britain, Ireland, and southern Europe as the result of the fact that industrialization happened later and less dramatically in these areas. Plausibly, it could be argued that recent economic booms in Spain and Ireland will help complete the process of change from stem to nuclear families, as children leave home earlier and travel further in pursuit of greater economic opportunities elsewhere. In a similar vein, it is possible to argue that the correlations between education and absolute nuclear families indicate that improved education frees children from dependency on their parents, rather than the idea that absolute nuclear families promote higher education to facilitate their offspring's independence.

However, there are several reasons not to dismiss the causative role of family structure in the correlations we have observed. First, it can be argued that the differences in family structure are of an older and more permanent nature than the differences in economic outcomes that we have attributed partly to them. Todd established the distinct patterns of family structure from records dating back to a time long before the industrial revolution. As a result, it is difficult to attribute the establishment of distinct family structures to economic developments in the modern era. Second, while it is very likely that industrial development has impacted upon all family structures and helped create a convergence towards the 'absolute nuclear' type, 
this in no way precludes the significance or the plausibility of nuclear, liberal family types helping to provide the conditions in which industrialization could take off in the first place. Third, current regional disparities, such as the structural changes towards the service sector, continue to develop in correlation to family structure patterns, despite the fact that the revolutions in industry, technology, and universal education have spread more or less evenly throughout Europe. The norms, social rules, and conventions that affect socio-economic disparities could - using Binmore's (2005) ‘cultural evolution' framework - be transmitted from generation to generation, via persuasion and emulation, directly using instruments such as family types, or indirectly through the reproduction of these family types in other institutions.

While the reverse causation from economic or other social changes to family structure change is of obvious and undeniable importance, it complements rather than contradicts our general hypothesis; as Greif suggests, both directions of causation probably interact in a self-reinforcing manner.

The position of social capital in this account also has potential for controversy. Whereas Greif (2005) and others (Coleman 1988, 1990) have seen the growth of social capital as replacing family structures throughout Europe, it maybe possible to argue that absolute nuclear family structures have merely allowed the formation of a particular sort of social capital in certain regions which did not become so prevalent elsewhere. This view is certainly supported by the results in terms of egalitarian nuclear and absolute stem families, but not in the cases of incomplete stem family or communitarian dominated areas. The persistence of strong family relations, at least until the death of the parents, in nuclear egalitarian family dominated areas, such as 
southern Italy or central and southern Spain, has been argued to act as a hindrance in the development of fully-fledged societal institutional systems and, eventually, as a barrier to economic development (compare Banfield, 1957 or Trigilia, 1992, for the case of the Italian Mezzogiorno). The measurement of social interaction with friends, however, shows virtually no correlation with our categories - and the national dummies indicate that this is determined much more by national habits than family structure.

Associations between education and household size might also be used to support our general hypothesis. The results in Table 5 indicate that the offspring of absolute nuclear families are more likely to be educated beyond secondary level. Education can also be linked exogenously to absolute family structures by arguing that, if one cannot depend on either the support of one's family or on an inheritance, then there is a greater motivation to ensure you are educated and able to take advantage of whatever economic opportunities are presented. This might also be linked to household size, by pointing out that two of the three family types that have lower levels of postsecondary education (egalitarian nuclear and stem incomplete) also tend to generate larger households. As such, it may be possible to argue that smaller family size, and therefore greater concentration of resources makes it easier for absolute nuclear families to send their children to university (Becker, 1960). Indeed, Todd (1991) has argued that inegalitarian families are likely to be smaller than egalitarian ones, as it is more difficult to see more children settled when only one child receives the bulk of the inheritance. The results offer support for this view. 
Our general employment indicator suggests little directly, hinting merely at the overall superior economic performance of the absolute nuclear areas. This fits the overall story of the generally advantageous position of absolute nuclear areas, and also supports Reher's (1998: 216) theory that, in general, areas around the Mediterranean (dominated by egalitarian nuclear and stem absolute family types) have a higher rate of unemployment, related in part to the greater ability of the family to provide support. As with many other social (as opposed to economic) indicators there is also difference between egalitarian and absolute nuclear in terms of the ratio of women in the workforce. In this case we note that our findings concur with the view that women are more likely to enter and/or remain in the workforce when they have fewer children (Wong and Levine, 1992) - supported tentatively by the correlation in our data between average household size and this ratio.

The final indicator to be considered shows that areas with an absolute nuclear family tradition have greater inequality than indeterminate, communitarian, and incomplete stem areas. There is no significant difference, however, between absolute nuclear and either egalitarian nuclear or absolute stem families. Given our argument so far, and its support of the traditional views of the 'Anglo-Saxon' and continental models, the higher level of inequality in absolute nuclear areas is perhaps unsurprising. It is also to be expected, perhaps, that the inegalitarian absolute stem families do not show a marked difference. However, the lack of any statistically significant difference between absolute nuclear and egalitarian nuclear areas in this regard is rather surprising. It could be hypothesized that in the latter case, the source of inequality might be from higher structural unemployment due to stagnation rather than from economic dynamism, but this is clearly only the most tentative of suggestions. 
To summarize the identified characteristics of each family type, we can suggest the following:

Regions with absolute nuclear families tend to be associated with smaller households, a more educated population, and a higher percentage of population in employment. As a rule, they have higher levels of formal club membership, perhaps as a form of compensation for the lack of socialization within the family. They are generally associated with service societies and tend to have richer and more dynamic regions, although also more inequitable societies. Regions with an imprint of absolute nuclear families seem to be early adopters, first in terms of the transition between an agricultural and an industrial society and then from the industrial to the service society. It thus may be that the higher economic dynamism of these areas is most in evidence in periods of change and less so in periods of stability.

Regions where egalitarian nuclear families tended to predominate have larger households, lower overall levels of educated population, lower activity rates, and lower female participation in the labor force. A small but more universally available inheritance maybe seen as a deterrent for higher education, as would the larger family size. While there is no big difference with absolute nuclear family areas in terms of sectoral structure, inequality, and dynamism, these regions tend to be poorer, perhaps as a result of their weaker ability to adapt to sectoral shifts in the economy.

Regions with a tradition of stem families seem to be associated with larger household size, lower levels of education, and lower participation in the labor force, 
but not necessarily lower female participation. They are currently predominantly industrial societies and tend to be poorer and less dynamic than nuclear family dominated areas, especially in times of structural change.

Regions with communitarian family traditions are surprisingly not linked to bigger households, or less educated populations, or less overall participation in the workforce. Such regions tend to be manufacturing societies and poorer, but more equal, than areas of absolute nuclear family traditions.

A potential criticism of these results relates to the focus on family structure as the sole explanatory variable, while omitting a host of other variables that may have an influence on our independent variables. Differences in wealth, economic growth, family size, education, employment levels, or female participation may be the consequence of a host of factors that go beyond family structures and no explanatory variable is completely robust against the addition of extra variables (Sala-i-Martín et al, 2004). In fact, most of our dependent variables could be used as independent variables to explain, say, differences in wealth or economic growth. Education, labor force participation, or sectoral structure, for example, are generally regarded as key determinants of growth. There are, however, several reasons that have motivated us to overlook what can be considered as 'proximate' (e.g. education, sectoral structure, employment) rather than 'deep' (e.g. family structures) causes of regional disparities. First comes the fact that the problems of endogeneity mentioned earlier are more prone to exist with the use of 'proximate' factors. It is more likely for recent economic growth to affect employment levels, female participation, or education than regional family structure traditions. Second, other 'proximate' causes may, in turn, 
reflect 'deeper' factors. Finally, when regressing family structures together with other 'proximate' factors, such as demographic structure, education, labor force participation, social capital, or sectoral structure on economic performance, the family structure factors are more robust than any of the 'proximate factors'.

But what about other 'deep' factors that may influence existing regional disparities in Europe? It is true that other 'deep' factors, such as history, culture, or religion, may affect regional change and disparities. However, the introduction of country effects controls for a large amount of the variation potentially caused by national institutions. In addition, the use of other 'deep' historical or institutional factors may create problems, as we expect history or institutions to affect families, but also for families to become a channel for the transmission of history and institutions. Consider the case of religion, whose current geographical distribution took place later than the formation of family structures used in this paper. Family structures may have been one of the factors shaping the diffusion of Protestantism after the Reform, while the establishment of Protestantism may have, to a certain extent, affected family structures. When we include family structures and religion together in one regression as a means to explain current disparities in two of our dependent variables (regional wealth and economic growth) ${ }^{9}$ (Table 6), we find that while the coefficients of the different family structures are barely affected with respect to those reported on Table

\footnotetext{
${ }^{8}$ Results of these regressions can be provided upon request.

${ }^{9}$ Regions are classified into regions with a Catholic, Protestant, or Anglican majority, depending on the main religion of the population. Regions with a Protestant majority are used as the base category. The sources of data are http://www.cia.gov/cia/publications/factbook; http://commons.wikimidia.org/wiki/Image:Europe religion map de.png; and http://csiint.org/world map europa religion.php.
} 
5 , the religious characteristics of regions tend to be dissociated from either current levels of wealth or recent economic performance. The sole exception is the higher performance of regions with a Catholic majority during the last three decades, as a consequence of the higher recent dynamism of regions in Ireland, Spain or of the Italian regions during the 1980s.

Table 6. Family types vs. religion

\begin{tabular}{|c|c|c|c|}
\hline \multicolumn{2}{|c|}{ Independent variables } & \multirow{2}{*}{$\begin{array}{l}\text { GDP per capita } \\
-5329.9^{* * *} \\
\end{array}$} & \multirow{2}{*}{$\begin{array}{r}\begin{array}{c}\text { Growth of GDP } \\
(\mathbf{1 9 7 5 - 2 0 0 4 )}\end{array} \\
-0.375^{*} \\
\end{array}$} \\
\hline \multirow{10}{*}{ 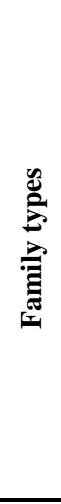 } & \multirow{2}{*}{ Egalitarian nuclear } & & \\
\hline & & 1955.9 & 0.206 \\
\hline & \multirow{2}{*}{ Stem } & $-2992,6 * *$ & $-0.289 * *$ \\
\hline & & 1365.7 & 0.143 \\
\hline & \multirow{2}{*}{ Incomplete stem } & $-4390.6 * *$ & $-0.642 * * *$ \\
\hline & & 2118.3 & 0.222 \\
\hline & \multirow{2}{*}{ Communitarian } & $-5410.7 *$ & -0.152 \\
\hline & & 2770.9 & 0.291 \\
\hline & \multirow{2}{*}{ Undetermined } & $-9430.5 * * *$ & $-0.548 * *$ \\
\hline & & 1856.5 & 0.240 \\
\hline \multirow{4}{*}{ : } & \multirow{2}{*}{ Mainly Catholic } & 712.8 & $0.416 * *$ \\
\hline & & 1570.2 & 0.167 \\
\hline & \multirow{2}{*}{ Mainly Anglican } & -713.1 & -0.055 \\
\hline & & 2910.5 & 0.231 \\
\hline & National dummies & Included & Included \\
\hline & df & 20,169 & 20,160 \\
\hline & Number of obs & 189 & 180 \\
\hline & $\mathrm{F}$ & 10.30 & 17.72 \\
\hline & R-squared & 0.55 & 0.83 \\
\hline & Adj R-squared & 0.50 & 0.69 \\
\hline
\end{tabular}

\section{Conclusions}

The arguments put forward above indicate that the links between family structure and socio-economic outcomes deserve attention and may offer significant progress towards understanding why some regions are richer, have different levels of social 
capital, are more able to adapt to sectoral shifts, or are more unequal than others. This is the case whether or not stem and communitarian families in the areas in which Todd identified them still remain or have been replaced by nuclear families; what is clear is that at least some associations seem to persist, and that these links have rich explanatory potential. While settling the controversies regarding the direction and nature of the causal processes involved is beyond the scope of this paper, our most plausible hypotheses all suggest some causative influence flowing from family structure to the persistence of disparities in social and economic development across Europe. It is also worth noting that these results would seem to suggest that Reher's (1998) criticism regarding the over-complexity of Todd's classification is misplaced, as we can see that significant differences emerge not just between northern and southern Europe, but also along the lines of authority and liberty and equality and inequality that Todd identified.

Our conclusions go beyond merely reinforcing the belief that the societies and economies of southern and eastern Britain, north west France, and the shores of the North Sea are stronger and more adaptable. By appearing to confirm that either family structures or their influence persist to the present, and may have a strong influence on growth and dynamism, our research suggests that any attempt to replicate that dynamism, labor mobility, or sectoral shifts elsewhere in Europe through targeted projects and investment may reap weaker dividends than expected. As well as the traditionally cited causes of regional disparity, such as peripherality or lower endowments of human capital and infrastructure (Rodriguez-Pose and Fratesi 2004), policy makers may need to deal with institutional barriers related to inherited family structures and cultures particularly resistant to change. Indeed, it could be argued that 
this is part of the evidence we require in order to explain why the impact of policy intervention in the past has been limited.

The results of this paper may also have a bearing on the current debates in social capital regarding the origins, roles, and value of community and society type institutions. Families, or kinship groups could be seen as 'concentrated' or exaggerated forms of community, given their even more limited geographical spread, the more intense personal relationships, and even stronger barriers to entry. However, nuclear families are somehow less 'family-like' than other, stronger forms of kinship in communitarian or stem family dominated areas, as there are much weaker personal links and more movement and mixing. In this way, it could be argued that in some ways, the differences between nuclear and stem families reflects the differences between society and community described in the social capital literature. Alternatively, we might investigate, as does Greif (2005), whether different family structures produce differing emphases on community and society, where nuclear families may be expected to lead to stronger society type institutions, and stem and communitarian family structures to stronger community type institutions. Whatever interpretative framework is used, it is reasonable to conclude that family structure deserves to be a fundamental component of the society and community debate.

To some extent, we have only established that there are important questions to answer, rather than actually providing answers itself. Apart from attempting further analysis of the nature of the causative processes that have produced our correlations, other questions emerge. How much longer will the influence of family structures last, and what shape might it take in the future? Given the fact that the upheavals of the last 
200 hundred years appear to have had little effect on the associations that family structure has with social and economic outcomes, perhaps we should expect its persistence to remain. On the other hand, it might be the case that mass migration and globalization will finally cause the patterns identified here to fade away. 


\section{Acknowledgements}

We are grateful to Alejandra Castrodad-Rodríguez for outstanding assistance with GIS and to Thomas Farole, Gernot Grabher, four anonymous referees, as well as to participants in seminars at the Universities of Cambridge, Oxford, Warwick, and Paris for their valuable comments to earlier versions of the paper. Duranton gratefully acknowledges financial support from the Canadian Social Sciences and Humanities Research Council and Rodríguez-Pose that of Prociudad-CM. The work was also part of the research programme of the independent UK Spatial Economics Research Centre funded by the Economic and Social Research Council (ESRC), Department for Business, Enterprise and Regulatory Reform, Communities and Local Government, and the Welsh Assembly Government. The views expressed are those of the authors and do not represent the views of the funders. 


\section{References}

Acemoglu, D., Johnson, S. and Robinson, J. A. (2001): The colonial origins of comparative development: An empirical investigation, American Economic Review 91(5), 1369-1401

Acemoglu, D., Johnson, S. and Robinson, J. A. (2005): Institutions as the fundamental cause of long-run economic growth, in Handbook of Economic Growth, editors Philippe Aghion and Stephen Durlauf, Amsterdam: Elsevier B.V., 385-472

Banfield, E. C. (1958): The moral basis of a backward society. Glencoe, Ill.: Free Press.

Becattini, G. (1987): Mercato e forze locali. il distretto industriale, Bologna, il Mulino.

Becker, G. S. (1960): An Economic Analysis of Fertility, in: National Bureau of Economic Research (ed.): Demographic and Economic Change in Developed Countries, Princeton, 1960, pp. 209-231.

Berry, B. (2000): Household type and the demographic transition, Population \& Environment, 21(3), 281-293.

Binmore, K. (2005) Natural Justice, Oxford: Oxford University Press.

Bisin, A., and Verdier, T. (2000): "Beyond the melting pot": Cultural transmission, marriage, and the evolution of ethnic and religious traits, Quarterly Journal of Economics, 115(3), 955-988.

Briant, A., Combes, P.P., Lafourcade, M. (2008) Dots to boxes: Do the size and shape of spatial units jeopardize economic geography estimations?. CEPR Discussion Paper 6928 www.cepr.org/pubs/dps/DP6928.asp

Coleman, J. S. (1988): Social Capital in the Creation of Human Capital, American Journal of Sociology, XCIV, S95-S120.

Coleman, J. S. (1990): Foundations of Social Theory (Cambridge, MA: Harvard University Press.

Durkheim, E. [1893] (1947): The division of labor in society (Translated by George Simpson). New York: The Free Press.

Durlauf, S. and Fafchamps, M. (2004): Social capital. Working paper W10485. Cambridge, Mass.: National Bureau of Economic Research.

Greif A. (2005): Family Structure, Institutions, and Growth: The Origin and Implications of Western Corporatism. Stanford University. Prepared for an AEA session on: The Family, Institutions, and Economic Growth. 
Greif, A. (2006): Institutions and the path to the modern economy: Lessons from medieval trade. Cambridge: Cambridge University Press.

Gross, R. and McIlveen, R. (1998): Psychology: A new introduction, London: Hodder and Stoughton.

Mamadouh, V. (1999): A political-cultural map of Europe. Family structures and the origins of differences between national political cultures in the European Union, GeoJournal 47: 477-486.

North, D. C. (1990): Institutions, institutional change and economic performance, New York: Cambridge University Press.

Parto, P. (2005): Economic activity and institutions: Taking stock, Journal of Economic Issues, 39(1): 21-52.

Portes, A (1998): Social Capital: Its origins and Applications in Modern Sociology Annual Review of Sociology, 24: 1-24

Putnam, R. (1993): Making democracy work. Princeton, NJ: Princeton University Press.

Putnam, R. (2000): Bowling alone: The collapse and revival of American community. New York, NY: Simon and Schuster.

Reher, D. S. (1998): Family ties in Western Europe: Persistent contrasts. Population and Development Review. 24(2): 203-234

Rodríguez-Pose, A. and Crescenzi, R. (2008) R\&D, spillovers, innovation systems and the genesis of regional growth in Europe. Regional Studies, 42(1): 51-67.

Rodríguez-Pose, A. and Fratesi, U. (2004): Between development and social policies: The impact of European structural funds in Objective 1 Regions, Regional Studies, 38(1): 97-113.

Rodríguez-Pose, A. and Storper, M (2006): Better rules or stronger communities? On the social foundations of institutional change and its economic effects, Economic Geography 82(1): 1-25.

Rokkan, S. (1970): Nation-building, cleavage formation and the structuring of mass politics. in: Citizens, elections, parties: Approaches to the comparative study of the processes of development. Oslo: Universitetsforlaget, 72-144.

Rokkan, S. (1981): Territories, nations, parties: toward a geoeconomic geopolitical model of the explanation of variations within Western Europe. in: R.L. Merritt/B.M. Russett (eds) From national development to global community. London: Allen \& Unwin, 70-95. 
Sala-i-Martín, X., Doppelhofer, G. and Miller R.I. (2004) Determinants of long-term growth: A Bayesian averaging of classical estimates (BACE) approach, American Economic Review 94(4): 813-835.

Schultenover, D. (1999): An anthropological view of the modernist crisis, Journal of Religion and Society 1: http://moses.creighton.edu/JRS/pdf/1999-7.pdf.

Schumpeter, J.A. (1926): The theory of economic development, Cambridge: Harvard University Press.

Scott, R.W.(2001): Institutions and organizations, $2^{\text {nd }}$ ed. London: Sage Publications.

Scott Smith, D. (1993): The curious history of theorizing about the history of the western nuclear family, Social Science History,17(3): 325-353.

Smith, R. (1996): Charity, self-interest and welfare: reflections from demographic and family history. In Charity, self-interest and welfare in the English past, edited by M. Daunton. London;UCL Press.

Storper, M. (1993): 'Regional "worlds" of production: Learning and innovation in the technology districts of France, Italy and the USA', Regional Studies, 27(5): 433455.

Storper, M. (1997): The regional world: Territorial development in a global economy Guilford Press.

Storper M., (2005): 'Society, community and economic development', Studies in Comparative International Development 39(4):30-57.

Tabellini, G. (2005): Culture and institutions: Economic development in the regions of Europe, CESinfo working paper no.1492, Category 5: Fiscal Policy, Macroeconomics and Growth, July

Todd E. (1990a) : L'invention de l'Europe. Paris: Seuil.

Todd E. (1990b): La nouvelle France. Paris: Seuil.

Todd E. (1991): The making of modern France: Politics, ideology and culture. Trans. A. and B. Forster. Oxford: Basil Blackwell.

Tönnies, F. [1887] (1957): Community and society (Gemeinschaft und gesellschaft) Charles P. Loomis (trans. and ed.), East Lansing: The Michigan State University Press.

Trigilia, C. (1992): Sviluppo senza autonomia. Effetti perversi delle politiche nel Mezzogiorno Bolonga: Il Mulino.

Weber, M. [1921] (1968): Economy and Society, translated by Roth and Wittich, New York: Bedminster Press. 
Wong, R and Levine, R (1992): The effect of household structure on women's economic activity and fertility: Evidence from recent mothers in urban Mexico, Economic Development and Cultural Change, 41(1): 89-102. 


\section{Appendix}
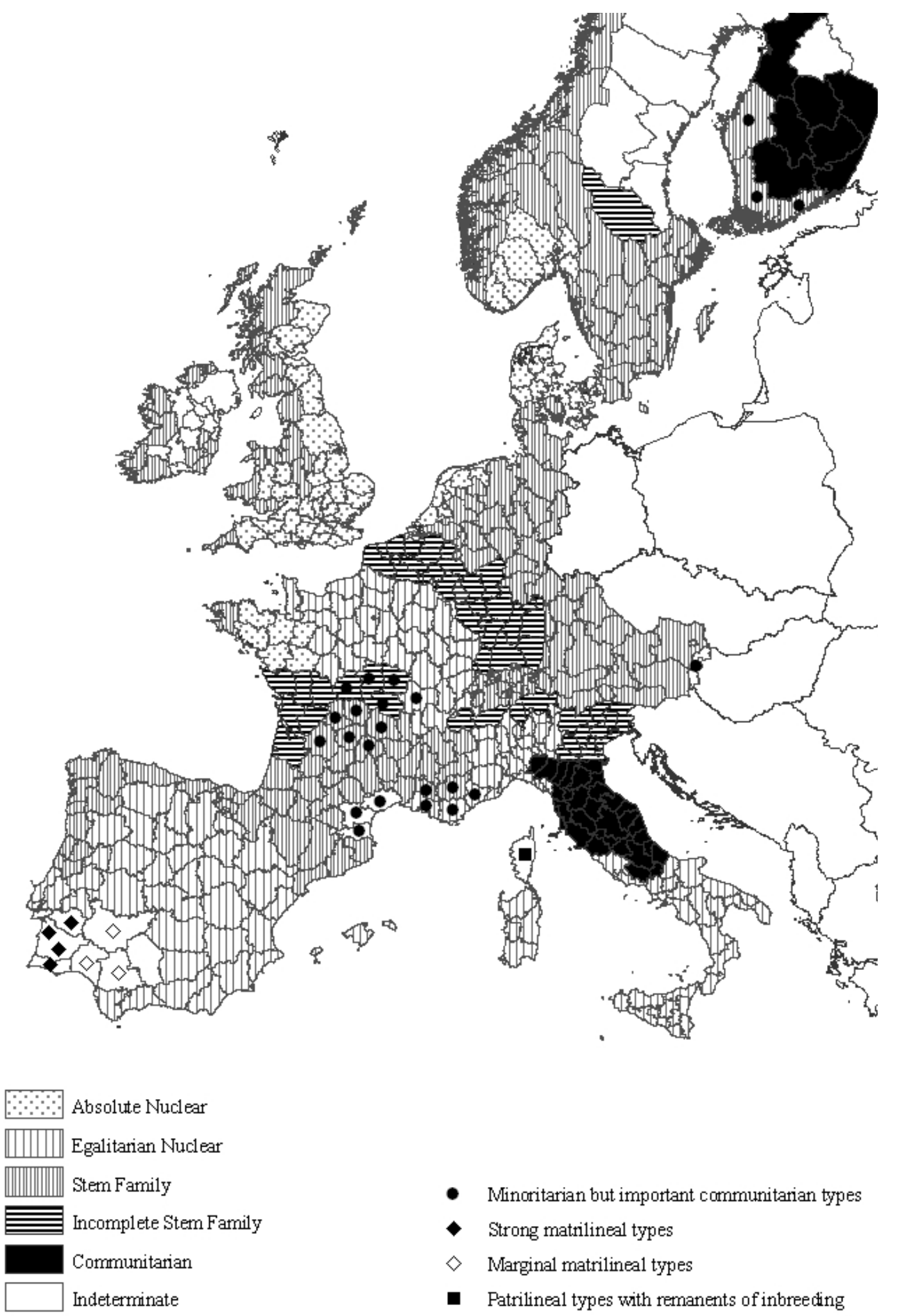

Figure A1. Todd's map of family types in western Europe (Source: Todd, 1990a) 


\section{BERR}

\section{Spatial Economics Research Centre (SERC)}

London School of Economics

Houghton Street

London WC2A 2AE

Tel: 02078523565

Fax: 02079556848

Web: www.spatialeconomics.ac.uk

SERC is an independent research centre funded by the Economic and Social Research Council (ESRC), Department for Business, Enterprise and Regulatory Reform (BERR), the Department for Communities and Local Government (CLG) and the Welsh Assembly Government. 